UDC: $811.111^{\prime} 4$

https://doi.org/10.31548/philolog2021.03.031

\title{
LINGUAL CHARACTERISTICS OF PARENTAL COMMUNICATION IN FAMILY FILM TEXTS
}

\author{
O. V. SKOBNIKOVA, Candidate of Philological Sciences, Senior Lecturer, \\ National Technical University of Ukraine "Igor Sikorsky Kyiv Polytechnic Institute" \\ E-mail: skobnikovaov@gmail.com \\ https://orcid.org/0000-0002-6453-6168
}

\begin{abstract}
The article focuses on the analysis of the linguial characteristics of parental communication on the basis of English-language family film texts. The object of the study is family communication, and its subject is the specifics of the lingual realization of the basic roles of family members, namely parents and children, represented in modern American family film texts, in which we can observe a shift of interest from sibling communication to parental communication.

The paper examines parental communication, which is defined as one of the main types of personality-oriented communication in the family sphere. As a result of the analysis of dictionary definitions, taken from seven dictionaries of the American version of the English language, the main components of the meaning of the word family were identified. Six of them contain the designation of paternity, therefore we stated that relations between parents and children is a key component of family communication.

The words to denote father predominate in number and that confirms that in Hollywood family films the main role is given to the relationship between children and their father. In recent years, due to the changing social role of women, although a figure of the father remains a key one in family films, modern films mostly focus on "the father-daughter story". Quantitative analysis of fragments of communication between parents and children, taken from film texts intended for family viewing, shows that communication between them is represented mostly in the form of a dialogue.

During the communication of parents and children, various communicative situations arise, in each of which communicators use certain strategies. The strategy of cooperation is implemented by maintaining constant communicative contact, both for informational and influential communication, and for metacommunicative communication (expressing a positive assessment of the partner) and is expressed in agreement and desire to avoid conflict. The strategy of confrontation is implemented by expressing a temporary negative attitude towards the partner, disagreement with a parent or a child. The strategy of neutrality is implemented by avoiding conflicting topics of conversation and ignoring them.
\end{abstract}

Key words: family communication, parental communication, communicative situations, linguial characteristics, parents and children, family film texts.

Introduction. At the beginning of the XXI century, the problems of communication, came to the forefront of linguistics and science in general. The study of family problems and family values becomes especially relevant. These questions are of theoretical interest to many branches of science, namely social philosophy, sociology, history, psychology, psycholinguistics, linguistics and other humanities.

Within the anthropocentric research paradigm, the interest in the linguistic personality as an object of linguistic research shifts the focus of research from the actual language system to communicative activity. Communication in the family as a complex multifunctional system that performs interdependent economic, economic, reproductive, educational functions, family communication as an integral element of social life most accurately represents the mental and speech activity of family members.

Of particular interest is the study of the peculiarities of the linguistic implementation of family communication on the material of film texts, which has not yet been conducted by either Ukrainian or foreign linguists. Family film is a world of ideas that children, adolescents and adults implement in their minds [5], which is why family communication, although reflected in many aspects of American language culture, is extremely widely represented in films intended for family viewing.

Family films combine concepts of how family members should behave at home and the image of the family they want to present to others in society. This "family identification" is often based on the ideas of morality, social norms, and responsibilities that families have within a larger society. Such moral construction includes information on how to behave with others, how to build and develop relationships and how to understand the world in general, and is aimed at both emotional and cognitive development of children [9, p.5-10].

It is worth noting that the term "family film" is essentially an American term, and in Europe the term "children's film" is mostly used [1]. However, the difference is not only in terminology. In American family films, the story is told mostly from the point of view of adults or parents. Instead, 
European children's films are told from the child's point of view, depicting the story through different emotions and experiences of the child him- or herself. A good example of this discrepancy is the American family film "Honey, I Shrunk the Kids", which, if it were a European children's film with a similar plot, would be called "Sis, Dad Shrunk Us". Therefore, in American films we can observe a shift of interest from sibling communication to parental communication.

Recent researches and publications. At present family communication is studied by experts in various fields, such as psychology, sociology, philosophy. In the field of linguistics in the study of family communication, researchers focus on modern changes in typical family communication (Adriana Bigari), conflict and cooperative speech interaction (Iryna Frolova), gender and age characteristics of cooperative speech behavior (Antonina Semenyuk), the main strategies of family discourse (Oksana Brovkina), specific family language (Valentyna Drobotenko), role relations in the family (Olena Grydasova), the organization of marital (Eugenia Zymytch) and sibling (Iryna Osovska) relations, children's discourse (Victoriya Kozlova). However, parental communication, which is the interpersonal communication between parents and children, still remains the subject of modern linguistic research.

The purpose of this research is to analyze the main characteristics of family communication between parents and children. The material of the study was micro-dialogues between family members, separated by a method of continuous sampling from family films of XX - early XXI centuries. The object of the study is family communication, and its subject is the specifics of the linguistic realization of the basic roles of family members, namely parents and children, represented by modern English-language movies intended for family viewing.

In order to reach the objective of the research and accomplish its tasks, the author resorted to a number of general scientific methods, namely analysis and synthesis, induction and deduction, quantitative analysis, as well as linguistic methods of analysis, namely discourse, speech act, contextual and corpus analysis.

Results. Family communication is considered to be a natural initial type of communication, which is assimilated into ontogenesis and develops throughout a person's life. Its characteristic features are a high degree of spontaneity of communication, situational dependence, relative subjectivity in solving common everyday problems and, as a result, violation of logic, free operation of structural, lexical-grammatical and stylistic means, utterance and high concentration of nonverbal communicative components [12].

The main types of personality-oriented communication in the family-domestic sphere are matrimonial communication ("husband - wife"), parental communication ("parents - children"), sibling communication ("brothers - sisters"). We distinguish these types according to the sociosituational parameter or sphere of functioning, using the classification of Iryna Shevchenko and Olena Morozova [13]. Note that communication in the family is a central link in everyday discourse. Typical features of communication in the family and domestic sphere are the irrelevance of the official regulation of communicative behavior, ease, concentration on the intimate and a wide range of topics [4].

One of the types of family communication, characterized by the specifics of the subjectinformation content, due to the status-role configurations, is parental communication. As a result of the analysis of dictionary definitions, taken from seven dictionaries of the American version of the English language, namely $A$ Dictionary of the English Language: A Digital Edition of the 1755, Cambridge Dictionary Online, Collins English Dictionary - Complete and Unabridged, Longman Dictionary of Contemporary English, Merriam - Webster, Oxford Advanced Learner's dictionary of Current English, The American Heritage Dictionary of the English Language, we identified the main components of the meaning of the word family: group, unit, individuals, persons, parents, children, traditional, common, ancestry, head, roof, marriage. Definitions containing the designation of paternity, namely the basic unit in society traditionally consisting of two parents rearing their children, are present in six of them, with the exception of the first. So we can say that relations between parents and children is a key component of family communication.

Confirmation of this we find in the texts of the studied family film texts. The most widely used words referring to children are as follows (in descending order): kids, baby, son, children, child, daughter, junior, munchkins. The most widely used words referring to parents are as follows (in descending order): Dad, Mom, mother, father, parents, Daddy, Mommy, Mum, Pop, parent, folks, stepmother, stepfather, stepmom. The words to denote father predominate in number and that confirms the opinion of the American researcher Claire Jenkins, who claims that in Hollywood family films the main role is given to the relationship between children and their father and notes that the story is traditionally transmitted through the relationship between father and son, when "the father-son story" focuses on the transmission of hereditary family traits and traditions. However, the researcher notes that in 
recent years, due to the changing social role of women, although a figure of the father remains a key one in Hollywood family films, modern films mostly focus on "the father-daughter story" [7].

Quantitative analysis of fragments of communication of parents and children, taken from family movies, shows that communication between them takes place mostly in the form of dialogue. Dialogues between parents and children can be characterized by a kind of internal community of partners, the presence of a single subject of conversation and a certain freedom of exchange. As an example we can cite a dialogue between a daughter and her mother, which shows a huge role of a mother in a child's life.

MASIE: What did you sing me when I was little? Baby.

MOM: Um, like, you know, Rock-a-bye

MASIE: That's for babies.

MOM: So? Why don't you just close your eyes and try, okay?

MASIE: Okay.

MOM: I'll help you fall asleep.

"When the wind blows

The cradle will rock

When the bough breaks

The cradle will fall

Down will come baby

Cradle and all."

Are you sleepy?

MASIE: A little. ("What Masie knew")

We can also see cases of monologue communication, as in the following examples describing a role of a father.

And a Dad is an irreplaceable person in a girls' life. I mean think about it, there's a whole day, devoted to celebrating Fathers, right? Just imagine, someone's life without a Father. Never buying a Father's Day card, never getting their Father a birthday present, never sitting on their Father's lap, never being able to say, "Hi, Dad", "What's up, Dad?", "Bye, Dad, catch you later, Dad". A baby's first words are always Dada, aren't they? Then there's Daddy, Daddio, Pop, My old man... Not to mention, "Wait til your father gets home, and ..." ("Parent Trap")

GEORGE: I've always been a concerned parent. I'm big on car seats, seat belts, bed times, curfews, calling when you get somewhere, never running with a sharp object. What can I say? I'm a father. Worrying comes with the territory. ("Father of the Bride")

During communication between parents and children, various communicative situations arise, each of which is dominated by certain strategies. The analysis of film texts showed that the main ones are strategies of cooperation, confrontation and demonstration of neutrality.

The strategy of cooperation is implemented by maintaining constant communicative contact, both for informational and influential communication, and for meta-communicative communication (expressing a positive assessment of the partner) and is expressed in agreement and desire to avoid conflict.

MICHAEL: Hi Georgie! I've been around and thought that I could just come and say hello.

GEORGIE: I'm so glad you came. It wouldn't be any fun without you. ("Mary Poppins") ANNIE: Thank Mom for everything, okay? And Dad? I love you. I love you very much.

GEORGE: I love you too, Sweetheart. ("Father of the Bride")

Communicators often resort to compliment and praise as a means of expressing a positive assessment and a positive emotional state of the communicator (as a consequence of this assessment). An example of expressing sincere and spontaneous praise is approval in the form of a pleasant surprise caused by an unexpected result.

HALLIE: Here's our proposition. We go back to Dad's house, pack our stuff and the four of us leave on the camping trip.

ELIZABETH: Oh, honey, that's such a good idea! ("Parent Trap")

The strategy of neutrality is implemented by avoiding conflicting topics of conversation and ignoring them.

BILL: (to Mom) They give you any trouble?

MINDY: No, not at all! ("Boyhood")

The strategy of confrontation is implemented by expressing a temporary negative attitude towards the partner, disagreement with a parent or a child.

MOTHER: I am so tired of you playing this silly game! Just stop it!

JACK: No! You can't forbid me (“Little Men”)

The main linguistic form of realization of interpersonal family relations is conversational speech - direct personal communication, which involves situational conditionality and commonality of the base of speakers. In the colloquial speech of members of the English-speaking family there is a lack of clear regulation of literary norms, arbitrariness in the selection of lexical means (use of dialectisms, colloquial words, vulgarisms, jargon, humorous units) [10].

ROYAL: What's cooking, Pop?

HENRY: You'll see. ("The Royal Tenenbaums")

That family is like a piece of toast. No honey, no jam, just dry. ("My Big Fat Greek Wedding").

Boy, I thought my parents were crazy, but this is the craziest thing ever. ("Field of Dreams")

Family communication is characterized by the use of "home language" as a form of verbal and nonverbal communication of family members [14, 
p.5]. A characteristic feature of the dictionary of "home language" is the presence in the family communication of occasionalisms that implement non-standard nominations of family members and various household items [14, p.12].

ROYAL: What's cooking, Pop?

HENRY: You'll see. ("The Royal

Tenenbaums")

MINDY: Our family is going to grow bigger, Buddy. ("The Preacher's Wife").

Discussion. Parental communication is the communicative interaction of speakers who are related by family ties and belong to the same social group, namely parents and children. Parental communication is characterized by dialogicity, situationality, spontaneity and

\section{References}

1. Bazalgette, C. (1995) Unshrinking the kids: Children's Cinema and the Family Film. In front of the children: screen entertainment and young audiences. British Film Institute. P. 92-108.

2. Bighari, A. A. (2006) Dyskurs suchasnoji anghlomovnoji sim'ji [Discourse of a modern English family]. Candidate's thesis. Kyiv, 225 s. [in Ukrainian].

3. Brovkina, O. V. (2015) Strateghiji anghlomovnogho rodynnogho dyskursu $\mathrm{V}$ sytuacijakh vidvertogho spilkuvannja, utishannja, neporozuminnja [Strategies of English language family discourse in the situations of open communication, consolation, misunderstanding]. Candidate's thesis. Kharkiv, 20 s. [in Ukrainian].

4. Brovkina, O. V., Baranova, S. V. (2019) Rodyna vs dyskurs [Family vs Discourse] Psykholinghvistyka. T. 25(2), №2. S. 31-49. [in Ukrainian].

5. Bukina, V. S. (2017) Rolj kinoiskusstva v socialjno-nravstvennom i dukhovnom vospitanii detej na primere filjma "maljchik $v$ polosatoj pizhame" [A role of film art in a social and moral education of children]. Molodoj uchenij. №1. S. 21-25. [in Russian].

6. Frolova, I. Je. (2009) Strateghija konfrontaciji $v$ anghlomovnomu dyskursi [Strategy of confrontation in English language discourse]. Kharkiv: KhNU imeni V. N. Karazina, 344 s. [in Ukrainian].

7. Jenkins, C. (2015) Home Movies: The American Family in Contemporary Hollywood Cinema. London and New York. 288 p.

8. Kozlova, V. V. (2012) Realizacija vykhovnogho vplyvu $v$ anghlomovnomu parentaljnomu dyskursi: strukturno-semantychnyj ta praghmatychnyj aspekty [Representation of educational impact in English language parental discourse: structural, semantic and pragmatic informality. It is expressed through the main communicative situations of cooperation, rivalry and neutrality. The main linguistic form of parental communication is colloquial speech, which is characterized by dialogic nature, the use of colloquial words, vulgarities, jargon, humorous units and "home language".

Family communication is characterized by multifaceted structural, semantic, communicative and pragmatic content in terms of implementation in a particular communicative situation, so it is an extremely broad material for further scientific research. We see the prospect of our further research in the study of other types of family communication, namely matrimonial and sibling.

aspects]. Candidate's thesis. Kharkiv, 2012. 20 s. [in Ukrainian].

9. Ochs, E., Kremer-Sadlik, T. (2007) Introduction: Morality as family practice. Discourse \& Society. №18. P.5-10.

10. Osovsjka, I. M. (2010) Strateghiji i preferentni taktyky parentaljnogho nimecjkomovnogho dyskursu [Strategies and preferable tactics of a parental German language discourse]. Naukovi zapysky. Vyp. 16. S. 240246. [in Ukrainian].

11. Semenjuk, A. A. (2007) Ghenderni ta vikovi osoblyvosti kooperatyvnoji movlennjevoji povedinky $v$ simejnomu dyskursi (na materiali suchasnoji anghlijsjkoji movy) [Gender and age specifics of cooperative communicative behaviour in a family discourse]. Candidate's thesis. Donecjk, $22 \mathrm{~s}$. [in Ukrainian].

12. Serghijenko, A., Baranova, S. V. (2010) Linghvo-komunikatyvni osoblyvosti dyskursu rodynnogho spilkuvannja [ Lingual and communicative features of a family communication]. Perekladacjki innovaciji: materialy Vseukrajinsjkoji studentsjkoji naukovopraktychnoji konferenciji. Sumy. S. 112-113. [in Ukrainian].

13. Shevchenko, I. S., Morozova, O. I. (2005) Dyskurs jak myslennjevo-komunikatyvna dijaljnistj. Dyskurs jak koghnityvno-komunikatyvnyj fenomen [Discourse as a mental and communicative activity. Discourse as a cognitive and communicative phenomenon]. Kharkiv. S. 21-28. [in Ukrainian].

14. Zymych, E. V. (2007) Osobennosti upotreblenija «domashnegho jazyka» v semejnom dyaloghicheskom diskurse [Peculiarities of using "home language" in a family dialogic discourse]. Materialy Vseukrajinsjk. nauk. foruma "Suchasna anghlistyka: koghnicija, komunikacija, tekst". Kharkiv. S. 23-24. [in Russian]. 


\title{
ЛІНГВАЛЬНІ ХАРАКТЕРИСТИКИ ПАРЕНТАЛЬНОГО СПІЛКУВАННЯ У СІМЕЙНИХ КІНОТЕКСТАХ
}

\author{
О. В. Скобнікова
}

Анотація. У статmі розглянуто лінгвальні характеристики спілкування батьків та дітей, досліджені на матеріалі англомовних сімейних кінотекстів. Об'єктом дослідження $\epsilon$ сімейне спілкування, а його предметом є специфріка мовної реалізації основних ролей членів сім'ї, а саме батьків та дітей, представлених у сучасних американських сімейних кінотекстах, в яких ми можемо спостерігати зміщення інтересу від спілкування сиблінгів до парентального спілкування. Парентальне спілкування визначено як один 3 основних видів особистісно орієнтованого спілкування у сімейній сфері, наряду з матримоніальним спілкуванням та спілкуванням сиблінгів.

В результаті аналізу словникових деффрініцій, взятих із семи словників американської версії англійської мови, було визначено основні компоненти значення лексеми family. Шість із них містять позначення батьківства, що дає нам підстави стверджувати, що стосунки між батьками та дітьми є ключовою складовою сімейного спілкування. Домінуюча кількість лексем на позначення батька підтверджує, що в сімейних Голівудських фільмах головна роль відводиться стосункам між дітьми та їх батьком. В останні роки через зміну сочіальної ролі жінок, хоча фрігура батька залишається ключовою у сімейних фрільмах, сучасні фрільми в основному зосереджуються на "історії батька і дочки".

Кількісний аналіз фрагментів спілкування між батьками та дітьми, взятих із текстів фрільмів, призначених для сімейного перегляду, показує, що що основною лінгвальною формою репрезентації парентального спілкування $\epsilon$ діалогічне розмовне мовлення. Під час парентального спілкування виникають різні комунікативні ситуації, в кожній з яких комунікатори використовують певні стратегії, основними з яких визначено стратегії кооперації, конфронтації та нейтралітету. Стратегія кооперації реалізується шляхом підтримання постійного комунікативного контакту, як для інфрормаційного та впливового спілкування, так і для метакомунікативного спілкування (виражаючи позитивну оцінку партнера) і виражається у згоді та бажанні уникнути конфлікту. Стратегія конфронтації реалізується шляхом вираження тимчасового негативного ставлення до партнера, незгоди з батьком або дитиною. Стратегія нейтралітету реалізується шляхом уникання суперечливих тем розмови та ігнорування їх.

Ключові слова: сімейне спілкування, парентальне спілкування, комунікація, комунікативні ситуації, лінгвальні характеристики, батьки та діти, сімейні кінотексти. 